\title{
Carving out Central Europe as a SPace of Legal Culture: A Way OUT of Peripherality?*
}

\author{
RAFAL MAŃKO*** \\ MARTIN $\check{S}_{K O P^{* * * *}}$ \\ MARKÉTA ŠTĚPÁNÍKOVA ${ }^{* * * * *}$
}

\section{INTRODUCTION}

It is quite typical for comparative legal research in our region to focus on one selected Central European legal system (usually the researcher's own jurisdiction) compared with a number of Western ones (e.g. "Legal institution $\mathrm{X}$ in Polish, German and French Law", or "Legal institution Y in Czech, German and Austrian law", and so forth). One may legitimately ask - why not "Legal institution Z in Polish, Romanian and Bulgarian law", not to mention comparisons with Russian, Uzbek or Armenian law? ${ }^{1}$ The same sadly also applies to legal theory, where many Central European scholars limit themselves to importing intellectual transfers from the West and implanting them in our intellectual universe. There is nothing inherently wrong in this, but the result is that we all know Dworkin and Hart ad nauseam,

DOI: $10.1515 /$ wrlae-2018-0002

* The Authors would like to thank Dr. Cosmin Cercel (Nottingham) and Mgr. Jakub Lakomy (Wrocław) for reading and commenting on an earlier version of this paper. All views expressed here are exclusively those of the Authors and do not present the opinion of any institution, body or organisation.

** PhD in Law (University of Amsterdam). External Fellow, Centre for the Study of European Contract Law, University of Amsterdam; Associated Researcher, Centre for Legal Education and Social Theory, University of Wrocław. Email: r.t.manko@uva.nl.

*** JUDr, Mgr, PhD; Associate Professor, Department of Legal Theory, Masaryk University, Brno. Email: martin.skop@ law.muni.cz.

**** JUDr, Bc, PhD; Assistant Professor, Department of Legal Theory, Masaryk University, Brno. Email: Marketa.Stepanikova@1aw.muni.cz.

${ }^{1}$ For conventional comparative legal science, analysing Uzbek, Belorussian or Macedonian law would amount to working on the law of an 'extraordinary place', far away from the conventional legal systems. For the notion of 'extraordinary place' in comparative law cf Esin Örücü, 'Comparatists and Extraordinary Places' in Pierre Legrand and Roderick Munday (eds), Comparative Legal Studies: Traditions and Transitions (Cambridge University Press 2003). We would like to thank Cosmin Cercel for drawing our attention to this concept. 
but who outside Poland knows Artur Kozak ${ }^{2}$ ? Or what do Romanian scholars know about Latvian legal theory (and vice versa)? The prevailing approach of a one-sided acceptance of intellectual transfers from the West not only do not help Central Europe to exit its well-known peripheral position vis-à-vis the juridical West, ${ }^{3}$ but actually amounts to a gesture of 'self-orientalisation' (as per Said's notion of 'Orientalism' ${ }^{4}$ ), accepting and strengthening the position of cultural inferiority inflicted upon us by hegemonic occidental discourses.

It is in precisely this context that the present paper hopes to contribute to promoting a counter-hegemonic discourse of Central (and Eastern) European legal identity, underscoring our legal-cultural bonds based on a common past, a common juridico-political mentality and a common present predicament. To this end, we hope to reinvigorate the discussion regarding Central Europe (or Central and Eastern Europe) as being a legal family in its own right, distinct both from Western European legal families (Romanic, Germanic, Common Law and Scandinavian) on the one hand, and the Eurasian legal family (post-Soviet), on the other. ${ }^{5}$ Believing that legal taxonomy can be seen as a matter of social construction of reality, ${ }^{6}$ and in any event it having a disciplining function, ${ }^{7}$ we hope to influence the discourses of comparative law with view to reframing the epistemic structures concerning our region. In turn, this can impact both the way we - Central and Eastern European jurists - perceive ourselves, and the way in which we are

\footnotetext{
${ }^{2}$ Artur Kozak (1960-2009) was one of the most original Polish legal theorists of the late 20th century, building his own system of legal philosophy - 'juriscentrism' (juryscentryzm). For the time being, however, both his works and works about his remain only in Polish. From Kozak's works, the most notable are his two books: Granice prawniczej wtadzy dyskrecjonalnej (Kolonia Limited 2000) and the posthumous one ed. by Maciej Pichlak: Myślenie analityczne $w$ nauce prawa i praktyce prawniczej (ed. Maciej Pichlak, WUWr 2010). From the literature on Kozak, see e.g. Paweł Jabłoński, Przemysław Kaczmarek, Michał Paździora and Maciej Pichlak, Perspektywy juryscentryzmu (Prawnicza i Ekonomiczna Biblioteka Cyfrowa 2011); Maciej Pichlak (ed), Profesjonalna kultura prawnicza (Scholar 2012); Maciej Pichlak, 'Artura Kozaka cierpliwość wobec prawa', (2014) 3.1 Filozofia Publiczna i Edukacja Demokratyczna 226.

${ }^{3}$ Rafał Mańko, Cosmin Cercel and Adam Sulikowski, 'Law and Critique in Central Europe: Laying the Cornerstone' in Mańko, Cercel and Sulikowski (eds), Law and Critique in Central Europe: Questioning the Past, Resisting the Present (Oxford: Counterpress, 2016) 2-7. Cf Damjan Kukovec, 'Law and the Periphery' (2015) 21 European Law Journal 406. See also Costas Douzinas, 'On a Recent Change of Tone in Politics and Law' in Law and Critique in Central Europe (n 3).

${ }^{4}$ Edward W Said, Orientalism (Penguin Classic 2003 [1978]). Cf Martijn W Hesselink, 'The New European Legal Culture: Ten Years On' in G Helleringer and KP Purnhagen (eds), Towards a European Legal Culture, ed. (Baden-Baden: C.H. Beck-Hart-Nomos 2014, available at SSRN: <https://ssrn.com/abstract=1519939> accessed 15 January 2018) 4.

${ }^{5}$ For a seminal paper in that direction see Rafał Mańko, 'Survival of the Socialist Legal Tradition? A Polish Perspective' (2013) 4.2 Comparative Law Review 1.

${ }^{6}$ Peter L Berger and Thomas Luckmann, The Social Construction of Reality (Penguin 1991 [1966]). Cf Tomasz Giaro, 'The Legal Tradition of Eastern Europe: Its Rise and Demise' (2011) 2.1 Comparative Law Review 1, 2: 'Rediscovering Central Europe, inventing Eastern Europe, imagining the Balkans - these fashionable titles convey the insight that all historicalgeographical nomenclature consists of socially-constructed concepts, promoting political projects in a discourse, the nature of which is apparently purely theoretical.'

${ }^{7}$ Michel Foucault, Surveiller et Punir. Naissance de la prison (Gallimard 1975). If we (Central Europe) are part of the Western legal tradition, as some claim, then we should follow the Western model, i.e. more precisely, mainly German/Austrian and French legal cultures. This is precisely the disciplinining function of taxonomy.
} 
perceived. Considering the 'death and burial' of the Socialist Legal Family ${ }^{8}$ as the founding myth of our regional juridical identity, we posit the succession of the former by two coexisting legal families: the Central European and the Eastern European/Eurasian ones. However, the paper does not intend to provide definitive answers to the questions of legal taxonomy of the postSoviet/post-socialist juridical space; its ambition is more moderate - to put forward a number of arguments in favour of a Central European Legal Family with the intent of destabilising the hegemonic 'return to Europe' approach ${ }^{9}$ and fostering a discussion of comparatists, legal theorists and socio-legal scientists focused on the problem of legal identity/identities of our region.

The main claim of the paper has a metatheoretical and critical character, and it boils down to the statement that the concept of Central (and Eastern) Europe in legal culture, and more specifically the concept of a Central European Legal Family, ought to be introduced owing to its emancipatory potential for the legal field in our countries. This is because, currently, the legal field in Central Europe suffers from symbolic violence ${ }^{10}$ which places it in a peripheral position, or even denies its existence. ${ }^{11}$ This

${ }^{8}$ Famously (pro)claimed by the Western German comparatist Hein Kötz, 'Preface to the Third Edition' in Konrad Zweigert and Hein Kötz, Introduction to Comparative Law (3rd ed., Clarendon Press 1996) v, and echoed in Tomasz Giaro, 'Some prejudices about the legal tradition of Eastern Europe' in Bronisław Sitek, Jakub J Szczerbowski and Aleksander W Bauknecht (eds), Comparative Law in Eastern and Central Europe (Cambridge Scholars 2014) 48 ('in my opinion, already today the socialist [legal] tradition can only be considered as effectively dead and buried').

${ }^{9}$ For a critical account of this narrative, see Rafał Manko, 'Demons of the Past? Legal Survivals of the Socialist Legal Tradition in Contemporary Polish Private Law' in Law and Critique in Central Europe (n 3) 68-74. A classic example of this narrative, negating our special juridico-taxonomic identity, is the following passage from Rafał T Stroiński: 'Polish law belongs to the western legal tradition, its laws for historical and cultural reasons belonging to the Germanic and Romanist legal families' ['Report from Poland' (2006) 3 European Company Law 39].

${ }^{10}$ On the notion of symbolic violence see Rafał Mańko, 'Symbolic Violence in Technocratic Law and Attempts at its Overcoming: Politicisation Through Humanisation?' (2017) 11 Studia Erasmiana Wratislaviensia 31. Pierre Bourdieu and Jean-Claude Passeron defined 'symbolic violence' as '[e]very power to exert symbolic violence, i.e. every power which manages to impose meanings and to impose them as legitimate by concealing the power relations which are the basis of its force, adds its own specifically symbolic force to those power relations' [Reproduction in Education. Society and Culture (SAGE 1990), p. 4] and Bourdieu added that symbolic violence is 'a gentle violence, imperceptible, and invisible even to its victims exerted for the most part through the purely symbolic channels of communication and cognition (more precisely, misrecognition), recognition, or even feeling.' [Masculine Domination (Stanford University Press 2001), 1].

${ }^{11}$ The utmost act of symbolic violence - a denial of Anerkennung in the precise Hegelian sense - was committed by the German comparatist Hein Kötz who, in his 1996 edition of the treatise on comparative law, decided to discard the chapter on the Socialist Legal Family without writing anything it its place, as our region disappeared into thin air or became colonized by the West overnight. See the now (in)famous passus from Kötz: 'The "socialist legal family" is dead and buried, and although it will take a long time to erase the traces of more than forty years of total subjection to political ideology, it seemed right to discard the chapters on socialist law" [Kötz (n 8) v]. For critical comments on this gesture of symbolic violence and denial of Anerkennung, see inter alia: Rafał Mańko, 'The Culture of Private Law in Central Europe After Enlargement: A Polish Perspective' (2005) 11 European Law Journal 527, 547-548; Hesselink (n 4) 4; Zdeněk Kühn, The Judiciary in Central and Eastern Europe: Mechanical Jurisprudence in Transformation? (Martinus Nijhoff 2011) 293. A similar denial of Annerkennung can be found in the works of classical $20^{\text {th }}$ century German 
symbolic violence remains in a vicious circle with the trauma of forced legal transplants, imposed upon Central Europe from times immemorial, by prevailing military, political or economic forces. Central Europe suffers from this symbolic violence - which is ex definitione 'gentle (...), imperceptible, and invisible', ${ }^{12}$ with the effect that the taking in of legal transfers from the West is completely naturalise ${ }^{13}$ (treated as obvious and normal), and not seen as a form of juridico-spatial hegemony, but as something that simply goes without saying. By promoting the concept of Central Europe in legal discourse (especially that of comparative law) we claim that it is possible to shift the discoursal structures and give a voice to our region, and at the same time destabilise the juridico-spatial hegemony to which we have been subject.

From a methodological standpoint, the paper pertains to a metatheoretical discourse of legal science. ${ }^{14}$ It aims to provide arguments as to how the discourse could and should be restructured, and therefore has an $a$ priori character towards specific legal discourses, such as those of comparative legal science, legal philosophy or individual dogmatic legal sciences. To put it in other words, our paper has a meta-socio-legal and metacomparative character; namely it provides arguments in favour of treating the notion of 'Central Europe', as understood in this paper, as a relevant taxonomical unit for socio-legal and comparative legal research. In this sense, our paper is normative, rather than merely descriptive or explanatory. The arguments we put forward here are of a multidisciplinary character, but pertain mainly to the domains of (legal) history and sociology (of law), as well as (the theory of) comparative law.

The paper is structured as follows. In section II entitled 'Where we come from', we first point out to the symptomatic character of the notion of 'Central Europe' (subsection II.1), before moving to a brief historical overview (subsection II.2), with particular emphasis on the three legal cultures we are most familiar with: the Czech, Polish (and partly also Slovak) ones. This historical overview provides the necessary background for section III, where we focus on the principal topic of this paper, namely whether we can speak today of a Central European legal family. We proceed by first introducing the theoretical criteria of legal taxonomy (subsection III.1 on legal families, followed by subsection III.2 on legal style), before applying them to Central Europe (subsection III.3). Having made a claim in favour of the Central European legal family, we feel obliged to touch upon the legal

legal historians - Paul Koschaker and Franz Wieacker - who in their widely known works (respectively, Europa und das römische Recht and Privatrechtsgeschichte der Neuzeit) 'completely omitted the development of private/ civil law in Central and Eastern Europe as though such regions did not exist in Europe', as pointed out by prominent Hungarian legal historian, Gábor Hamza, 'Continuity and Discontinuity of Private/Civil Law in Eastern Europe After World War II' (2006) 12 Fundamina: A Journal of Legal History 48.

12 Bourdieu (n 10) 1.

${ }^{13}$ For the notion of 'naturalization' see e.g. Hanna Dębska and Tomasz Warczok, 'The Social Construction of Femininity in the Discourse of the Polish Constitutional Court' in Law and Critique in Central Europe (n 3) 130.

${ }^{14}$ We are using the term 'legal science' in the sense of Rechtswissenschaft or science juridique (and in the same sense as the Anglo-Saxons speak of 'political science' or 'social science'), and as opposed to mere 'legal scholarship' (Rechtslehre, doctrine juridique). On this fundamental distinction (between legal scholarship/Rechtslehre and legal science/Rechtswissenschaft), see recently Tomasz Pietrzykowski, Naturalizm i granice nauk prawnych. Esej z metodologii prawoznawstwa (Wolters Kluwer 2017) 31-44. 
language(s) of our region (section IV), noting the problematic character of the commonplace use of English - a language not well adapted to express the ideas and notions of our legal family, as we posit. Finally, in section V we conclude with a moderately optimistic view upon the chances of our region to break out of legal peripherality.

\section{WHERE WE COME FROM}

\section{Central Europe as a Symptomatic Concept}

'Central Europe' is, in fact, a paradoxical term which, at the same time, conceals and reveals our regional pride and geopolitical aspirations coupled with our difficulty in coming to terms with the de facto peripheral status of our region in today's Europe. ${ }^{15}$ To put it in Lacanian terms, 'Central Europe' is a purely symptomatic concept: by ascertaining the alleged 'centrality' of our region in Europe, we repress at the same time our peripherality towards the actual centre - Western Europe. ${ }^{16}$ Does this mean, however, that we should not use the concept, or that we should yield, perhaps to the German approach whereby Mitteleuropa equals Germany, whilst our region can, at best, aspire to be Ostmitteleuropa? To the contrary, we believe that we should heed to Žižek's call to 'enjoy our symptom', ${ }^{17}$ and will therefore consciously argue that despite its political and economic peripherality, Central Europe is 'Central'. 18

To this end, we contend that objective geographical criteria should prevail and, taking into consideration that the geographical centre of Europe is located in the village of Suchowola in the Polish region of Podlasie, ${ }^{19}$ we claim that our region is quite rightly dubbed as 'Central' (rather than

\footnotetext{
15 The first attempts by legal scholars to speak openly about our peripherality were made very recently (and independently from each other) by the Slovenian academic Damjan Kukovec and the Polish academic Hanna Dębska (who, in a kind of semi-optimism, prefers to speak of semiperipherality). See: Kukovec (n 3) and Hanna Dębska, 'Strategia wielopozycyjności w półperyferyjnym polu prawnym. Homo academicus na rynku' in Tomasz Zarycki (ed), Polska jako peryferie (Scholar 2016). See also Mańko, Cercel and Sulikowski (n 3) 1-15.

${ }^{16}$ It could also be understood as a 'sinthome', i.e. no longer an enigma to be deciphered, but the way in which one enjoys its relation to the unconscious, in the sense used by Lacan in his Seminar XI. Encore. We would like to thank Cosmin Sebastian Cercel for drawing our attention to this potential reading of Central Europe's symptomal/sinthomal character. Cf Slavoj Žižek, The Sublime Object of Ideology [1989] (Verso 2008) 80: 'The symptom is not only a cyphered message, it is at the same time a way for the subject to organize his enjoyment - that is why, even after the completed interpretation, the subject is not prepared to renounce his symptom; that is why he "loves his symptom more than himself".

17 cf Slavoj Žižek, Enjoy your symptom! (Routledge 2001).

${ }^{18}$ For a meticulous overview of the various ways in which Central and Eastern Europe is classified in recent comparative law scholarship, see Katalin Kelemen and Balázs Fekete, 'How Should the Legal Systems of Eastern Europe Be Classified Today?' in Attila Badó et al (eds), International Conference for the 10th Anniversary of the Institute of Comparative Law of the University of Szeged (Universitätsverlag Potsdam 2014) 199-208. See also Katalin Kelemen, 'I sistemi giuridici dell'Europa orientale' in Vittoria Barsotti \& Vincenzo Varano (eds), La tradizione giuridica occidentale: Testo e materiali per un confronto civil law common law (5th ed. Giapichelli 2014).

19 'Geometryczny środek Europy' [The Geometrical Centre of Europe], <http://suchowola.fotopolska.eu/Suchowola/b59781,Geometryczny_srodek_Europy.html> accessed 15 January 2018.
} 
'Eastern') Europe. Hence, the 'old' EU Member States belong to Western, Northern and Southern Europe; the 'new' Member States, which acceded between 2004 and 2007, are 'Central' Europe, ${ }^{20}$ whilst former Soviet republics which remain outside the Union are 'Eastern Europe' 21 in the proper sense of the word or - possibly - the European part of Eurasia. ${ }^{22}$ Of course, under such a definition 'Central Europe' is somewhat extended, stretching from Estonia in the north to Croatia in the South, and from Romania in the east to the Czech Republic in the West, but we must keep in mind that juridical taxonomy need not coincide with pure geography; juridico-historical and juridico-comparative factors have precedence over a simplistic cartographical exercise.

What we wish to emphasise in this paper, is that the region - now also known as the 'intermarium' or 'trimarium'23 (respectively 'between-theseas', or 'of-the-three-seas', i.e., Baltic, Adriatic and Black) - does have more in common that just geographical proximity. A question which requires further study, both in a historical and contemporary dimension, is the status, in terms of legal families, of so-called 'Western Balkans', i.e. those countries of former Yugoslavia which are not part of the EU (Serbia, Montenegro, Bosnia and Herzegovina, Macedonia) as well as former USSR republics which are not currently taking part in the Eurasian forms of legal integration (the Eurasian Economic Union, which - as from 2014 - succeeded the Eurasian Economic Community). ${ }^{24}$ Whilst these liminal areas require further research, our further narrative will focus on the core of Central Europe which seems to include especially countries which are, entirely or partly, the nonGerman successors of the former Austro-Hungarian Empire.

\section{Central Europe in legal history}

The notion of 'Central Europe' as a legal point of reference cannot be constructed in abstraction from legal history (even if legal history is not the

\footnotetext{
${ }^{20}$ In alphabetical order: Bulgaria, Croatia, Czech Republic, Estonia, Hungary, Latvia, Lithuania, Romania, Slovenia, Slovakia.

${ }^{21}$ cf Gianmaria Ajani, Il modello post-socialista (3rd ed. Giapichelli 2008), who identifies numerous features common to Central Europe, and opposes them to features of Eastern European/Eurasian legal systems (ibid 73, 104, 118, 128-130).

${ }^{22}$ On Eurasia as a legal notion, as developed in the legal theory of Eurasian thinkers, see recently Булат Венерьевич Назмутдинов, Законы из-за границы: Политико-правовые аспекты классического евразийства (Норма 2017). Specifically on the borders of Eurasia according to classical Eurasianists see pp. 139ff.

${ }^{23}$ A translation (into Latin) of the respective Polish terms 'międzymorze' and 'trójmorze'. The concept of the Intermarium is older, see e.g. Thomas Lane and Marian Wolański, Poland and European Integration: The Ideas and Movements of Polish Exiles in the West, 1939-91 (Palgrave MacMillan 2009) 61ff, 158ff.

${ }^{24}$ Out of 17 former USSR republics, only 5 are members of the EEU: Armenia, Belarus, Kazakhstan, Kyrgyzstan and Russia. See the official website: <http://www.eaeunion.org/?lang=en> accessed 15 January 2018. The former Eurasian Economic Community (EaEC) was also composed of 5 ex-USSR republics: Belarus, Kazakhstan, Kyrgyzstan, Russia and Tajikistan. One should finally mention to the Community of Independent States as a form of Eurasian regional integration. On the EEU see e.g. Evgeny Vinokurov, 'Eurasian Economic Union: Current state and preliminary results' (2017) 3 Russian Journal of Economics 54. For a general overview, see e.g. Katarzyna Czerewacz-Filipowicz \& Agnieszka Konopelko, Regional integration processes in the Commonwealth of Independent States Area. Economic and political factors (Springer 2017).
} 
only factor to be taken into account in the construction of Central Europe). Starting from the Middle Ages, we can speak of a division of Europe along the lines of the reception of Roman law, Byzantine law and the lack of reception ${ }^{25}$ of any of the former. ${ }^{26}$ Western Europe - today's Germany, France, Italy and Spain - was subject to the reception of Roman law and its legal systems developed under its influence. England retained its own legal system - the Common Law - and resisted reception, as did the Nordic countries. South-Eastern Europe - including today's Greece and Bulgaria were subject to Byzantine law. Central and Eastern Europe did not receive either of the two ancient legal systems. Poland and Hungary - two major Central European countries at the time - resisted Roman law in the name of preserving domestic customary law. In this sense, Central Europe would denote the area in between the Romano-Germanic West and the ByzantineRussian East.

Whilst the subjection of Hungary to Habsburg rule did not lead to the erasing of Hungarian customary law (in force until 1959!), the dismembering of the Polish-Lithuanian Commonwealth - the Rzeczpospolita - had serious consequences for legal life, namely the disappearance both of customary Polish law and, some decades later, also of the codified Lithuanian law (the Statuty litewskie). ${ }^{27}$

During the $19^{\text {th }}$ century, Central Europe was the outback of four empires - the Austrian/Austro-Hungarian, ${ }^{28}$ the German (earlier: Kingdom of Prussia), the Russian and the Ottoman. What was in common, was that the territories of Central Europe were the periphery of various empires. The $20^{\text {th }}$ century brought about the proliferation of new nation-states in Central Europe. However, after 1945 the entire region found itself in the Soviet Bloc, or - in the cases of Yugoslavia and Albania - in socialist countries contesting the Soviet leadership of the communist world. However, the period between World War I and II also created a great deal of similarities between Central European countries which, after a brief period of (limping) parliamentary democracy found themselves, as a rule, sliding down into authoritarianism (as exemplified inter alia by Poland, Lithuania, Romania, Hungary and Yugoslavia). A common theme is the short-lived liberal-democracy which quickly gave way to a different form of government.

World War II brought about important reconfigurations on the maps of Central Europe, but it was the allied victory over Nazi Germany in 1945 which configured the region's place for the next 45 years. As such, Central

\footnotetext{
${ }^{25}$ Understood here as formal binding force, as opposed to an intellectual inspiration.

${ }^{26}$ On Roman law in European legal history see e.g. Peter Stein, Roman Law in European History (Oxford University Press 1999). As Giaro notes: 'An important distinguishing feature of Eastern Europe in the field of legal history is recognized, exactly as in the case of the traditional English legal system, as the non-reception of Roman law.' [Tomasz Giaro, 'Legal Tradition of Eastern Europe. Its Rise and Demise' (2011) 2.1 Comparative Law Review 1, 4-5].

${ }^{27}$ The Lithuanian Statutes were repealed by the Russian Empire in 1840 [Sławomir Godek, 'III Statut Litewski w dobie porozbiorowej - stan badań nad dziedzictwem prawa litewskiego' in W Walczak \& K Łopatecki (eds), Stan badań nad wielokulturowym dziedzictwem prawnym dawnej Rzeczypospolitej (Instytut Badań nad Dziedzictwem Kulturowym Europy 2010) 474].

${ }^{28}$ For more details see e.g. John W Mason, The Dissolution of the Austro-Hungarian Empire, 1867-1918 (Routledge 2014).
} 
Europe became rather part of Eastern Europe, and it was only in 1989 and the fall of the Berlin Wall that the region started to assert its identity both vis$\grave{a}$-vis the East and West.

All in all, it seems that it was the $19^{\text {th }}$ century which was crucial for Central Europe as being its formative period. This is because precisely at this moment the legal histories of Central European lands began to experience a common development, which brought them together for 200 years and still keeps them together. The commonality of this path has the following elements: 1) reception of foreign (Western) laws in the $19^{\text {th }}$ century ${ }^{29}$ (against the background of a tendency towards non-reception of Roman law before, as indicated above);2) independence and efforts at building a national legal culture; 3) Actually Existing Socialism; 4) post-socialist transformation; 5) EU integration. Stages (1) and (2) occurred sometimes in the reverse order (in the Balkans, where Central European countries first won their independence from the Ottoman Empire, and only then proceeded to a reception of Western law). Also not all countries in the region are experiencing stage (5).

What is important in juridico-historical and political terms is that today's Central Europe is comprised of countries whose modern independent statehood dates back either to the early $20^{\text {th }}$ century (Poland, Lithuania, Latvia, Estonia, Czechia, Slovakia, Hungary and Albania) or to the later $19^{\text {th }}$ century (Romania, Bulgaria, Serbia and Montenegro). Some countries are true newcomers to sovereign statehood, such as Slovenia and Macedonia. What is more, the current political map of Central Europe was drawn only in the 1990s, with the regaining of independence by the Baltic countries, as well as the break-up of Czechoslovakia and Yugoslavia into smaller state entities (fashioned as nation-states). The fact of being a politico-juridical space of relatively new countries, which emerged not from integration (like Italy or the $2^{\text {nd }}$ German Empire in the 1860s-1870s), but from breaking away and splitting, ${ }^{30}$ is also an integrating factor. Unlike Western legal communities, which have become used to (and perhaps even bored with) their independence, which they have enjoyed for centuries (even if with short intervals), Central European national legal communities were founded relatively recently. Furthermore, whilst borders in the West of Europe have been relatively stable (with exceptions), the borders within Central Europe have been prominently unstable, with consequences for legal systems and legal communities.

Of course, despite similarities and analogies, each Central European country's legal history displays its own particularities. The two states of the former Czechoslovakia are one interesting case study, illustrating the paths of Central European politico-juridical development. Historically, Czechia and Slovakia were politically separate (belonging to the Austrian and Hungarian states, respectively) but due to the political situation, often united in one

\footnotetext{
${ }^{29}$ Tomasz Giaro (ed), Rechtskulturen des modernen Osteuropa: Traditionen und Transfers, 2 vols. (Vittorio Klosterman 2006-2007).

${ }^{30}$ Even Poland, which emerged from the integration of parts of Germany, Austria and Russia in 1918/1921, was simply a triple breakaway from three former Empires. Likewise was Romania which, after 1918, integrated parts of former Ottoman, Austro-Hungarian and Russian empires.
} 
state. ${ }^{31}$ The Czech and Slovak languages are very similar but not identical. And still, in the first part of the 20th century the Czech and Slovak nations were presented as one 'Czechoslovak' nation. ${ }^{32}$ Naturally, this kind of schizophrenic understanding of nation also influenced a legal system and in the end it resulted in the separation of Czechoslovakia.

When, after the defeat of the Hussite revolution in Czechia, ${ }^{33}$ Catholic Habsburgs took power, the country became subject to the Austrian Empire, subject to linguistic, religious and juridical hegemony. When the Empire was divided into two parts, Czech lands stayed in the Austrian half and Slovak lands became a part of Hungarian half of the Empire. ${ }^{34}$ It is no surprise that the Czech attitude towards religion, sub-national political entities and even political power in the country has become at least suspicious and is still visible today also in the Czech legal culture.

A key factor bringing together the otherwise heterogeneous mass of Central European legal systems and cultures is the experience of Actually Existing Socialism, also (somewhat misleadingly) known as Communism. ${ }^{35}$ The impact of this period is visible in legal culture and legal mentality, not to mention also legal survivals in the legal system. For instance, if we speak of contemporary Czech legal culture, we need to emphasise that its formative elements include the heritage of the manipulated political processes of the fifties of the $20^{\text {th }}$ century, ${ }^{36}$ legal codes from the sixties based on the socialist worldview ${ }^{37}$ and socialist normativism which reigned in Czech jurisprudence for four decades. ${ }^{38}$ Various aspects of transformation (including the legal ones) have been questioned since the Velvet revolution itself ${ }^{39}$ and they are still present in the Czech RepublicCzechia; probably the most important of them are questions of the nature of rule of law, democracy and market economy. ${ }^{40}$ Nowadays, there are many attempts to solve the problematic

${ }^{31}$ For more details see e.g. Leslie C Tihany, 'The Austro-Hungarian Compromise, 18671918: A Half Century of Diagnosis; Fifty Years of Post-Mortem’ (1969) 2 Central European History 114.

${ }^{32}$ For more details see e.g. Carol Skalnik Leff, National Conflict in Czechoslovakia: The Making and Remaking of a State, 1918-1987 (Princeton University Press 2014).

${ }^{33}$ For more details see e.g. TA Fudge, 'The Hussite Revolution' (2004) 79 Speculum: A Journal of Medieval Studies 1142.

${ }^{34}$ For more details see e.g. Glenda Sluga, 'Bodies, Souls and Sovereignty The AustroHungarian Empire and the Legitimacy of Nations' (2001) 1 Ethnicities 207.

${ }^{35}$ Kühn (n 11) ch 2. For the Baltic states see e.g. Peter van Elsuwege, From Soviet Republics to EU Member States: A Legal and Political Assessment of the Baltic states' accession to the $E U$ (Brill 2008).

${ }^{36}$ See e.g. Milan Hauner, 'Crime and Punishment in Communist Czechoslovakia: The Case of General Heliodor Píka and His Prosecutor Karel Vaš’ (2008) 9 Totalitarian Movements and Political Religions 335.

${ }^{37}$ See e.g. George E Glos, 'Czechoslovak Civil Code of 1964 and Its 1982 Amendment within the Framework of Czechoslovak Civil Law 1984)', 6 New York Law School Journal of International and Comparative Law 215.

${ }^{38}$ Csaba Varga, Introduction. 'Complexity of the Challenge Facing Central and Eastern Europe' in Armin Hoeland Gessner and Csaba Varga (eds), European Legal Cultures (Dartmouth 1996) 421.

${ }^{39}$ Jiř́ Musil, 'Czechoslovakia in the Middle of Transition' (1992) Czechoslovak Sociological Review 5.

${ }^{40}$ Adrian Smith and Judit Timár, 'Uneven Transformations: Space, Economy and Society 20 Years after the Collapse of State Socialism' (2010) 17 European Urban and Regional Studies 115. 
heritage of the Communist past in the countries of the former Czechoslovakia. Westernization and globalization are naturally present in the process of transformation, ${ }^{41}$ but not necessarily as the best or only possible way to deal with this heritage. Lustrations, ${ }^{42}$ punishing the crimes of the Communist regime $^{43}$ or judicial decisions on the communist pasts of current Czech judges $^{44}$ are just few examples of a much more complex situation. At this moment, the most recent and most visible results of the transformation process both in the Czech Republic and in Slovakia are civil recodifications (in Slovakia this is still in progress) ${ }^{45}$ and discussion on the normative power of judicial decisions ${ }^{46}$ which was unthinkable under the socialist normative doctrine.

The Polish experience with the period of Actually Existing Socialism and post-socialism is, in terms of legal culture, a period of struggle between legal traditions - the two Western ones (Romanic, Germanic) and the Sovietsocialist legal tradition. This can be illustrated by drawing on the culture of private law. Directly after the War, the communists used the output of the Codification Commission of Civil Law and finished the task of unification (by 1946). ${ }^{47}$ Paradoxically, the codification was rather liberal (or 'bourgeois') in character and soon thereafter a process of Sovietisation of Polish law embarked upon. 1950 was an important date in this respect, as it saw the enactment of a Soviet-modelled act on the 'general provisions of civil law' (notably introducing the Soviet general clause of 'principles of social life' ${ }^{48}$ ), and a far-reaching illiberal reform of the Code of Civil Procedure (notably introducing the unlimited power of the public prosecutor to intervene in private civil proceedings). ${ }^{49}$ The drafting of a Civil Code was embarked upon, but remained unfinished until 1964. The final Civil Code was a compromise

\footnotetext{
41 Varga (n 38) 417.

${ }^{42}$ Kieran Williams, Brigid Fowler and Aleks Szczerbiak, 'Explaining Lustration in Central Europe: A “post-Communist Politics” Approach' (2005) 12 Democratization 22.

${ }^{43}$ See e.g. Adrienne M Quill, 'To Prosecute or Not to Prosecute: Problems Encountered in the Prosecution of Former Communist Officials in Germany, Czechoslovakia, and the Czech Republic' (1996) 7 Indiana International and Comparative Law Review 165.

44 See e.g. Zdeněk Kühn, Aplikace Práva Soudcem v éře Středoevropského Komunismu a Transformace: Analýza Př́ćin Postkomunistické Právní Krize (C.H. Beck 2005).

45 See e.g. Miloš Večeřa, Martina Urbanová and Markéta Klusoňová, Právní vědomí v teoreticko-empirickém pohledu (Masarykova univerzita 2015).

46 See e.g. Michal Bobek, Zdeněk Kühn, Pavel Molek, Radim Polčák and Ladislav Vyhnánek, Judikatura a právní argumentace ( $2^{\text {nd }}$ ed., Auditorium 2013).

47 Stanisław Grodziski, 'Prace nad kodyfikacją i unifikacją polskiego prawa prywatnego (1919-1947)' (1992) 1.1-4 Kwartalnik Prawa Prywatnego 9, 22; Stefan Grzybowski, 'Zagadnienia kodyfikacji polskiego prawa cywilnego (Organizacja i wyniki pracy 19191992)' (1992) 1.1-4 Kwartalnik Prawa Prywatnego 91, 103; Aleksandra A Kozioł, 'Organizacja prac nad prawem cywilnym w Polsce w latach 1945-1946' (2005) 7 Z Dziejów Prawa 174, 178.

48 See more in Rafał Mańko, Quality of Legislation Following a Transition from Really Existing Socialism to Capitalism: A Case Study of General Clauses in Polish Private Law in Janis Rozenfelds (ed), The Quality of Legal Acts and its Importance in Contemporary Legal Space (University of Latvia Press 2012).

${ }^{49}$ See e.g. Rafał Mańko, 'Is the Socialist Legal Tradition "Dead and Buried?" The Continuity of Certain Elements of Socialist Legal Culture in Polish Civil Procedure' in Thomas Wilhelmsson (ed), Private Law and the Many Cultures of Europe (Kluwer 2007); Anna Stawarska-Rippel, Elementy prywatne $i$ publiczne $w$ procesie cywilnym $w$ świetle prac kodyfikacyjnych w Polsce (1918-1964). Studium historycznoprawne (Wydawnictwo Uniwersytetu Śląskiego 2015) 159ff, $325 \mathrm{ff}$.
} 
between the Western Legal Tradition, where Polish legal culture had its roots, and the Socialist Legal Tradition. ${ }^{50}$ The post-1989 period, in turn, can be seen as an attempt at eliminating the traces of the Socialist Legal Tradition and deliberately 'westernising' Polish private law. The same also applied to public law, where - both in constitutional and administrative law - the main source of legal transplants has been the Germanic Legal Family, to mention the Rechstaat and the constitutional court as but two examples. All in all, the post-1989 period can be characterised as a new wave of legal transfers from Western Europe. ${ }^{51}$

This brings us to the fifth element in the historical development of the region, namely the recent common experience of transformation (from socialism to capitalism) and adaptation to EU law. ${ }^{52}$ We contend that all these factors strongly militate in favour of Central Europe - understood as comprising the former socialist countries now in the EU - to share a common legal space, both in terms of legal culture informed by legal tradition ${ }^{53}$ and by their present condition of being a periphery within the EU. ${ }^{54}$

The common themes of transformation, post-communism (e.g. lustration), Europeanisation/Westernisation build up a common research agenda and create the need for similar methodological approaches. Therefore, the contours of a common Central European legal culture extend not only to the social practices of law-making and adjudication, but also to academic legal culture. In order to give a flavour of the specificity of Central European legal cultures, it seems opportune to resort to two examples, each in its own right: Poland and the two successor states of former Czechoslovakia.

\section{A CEnTral European Legal Family? A Matter of STYLE}

\section{Defining Legal Families}

Let us now return to the principal question of this paper, namely whether we can speak of a 'Central European' (or, possibly, 'Central and Eastern European') legal family. This would mean placing Central Europe au par with generally accepted legal families in Europe, i.e. the Romanic, Germanic, Scandinavian (Nordic) and Common Law families. In order to answer this question it is necessary to adopt a certain definition of the notion of 'legal family' and then analyse Central European legal culture in light of

\footnotetext{
50 See e.g. Witold Wołodkiewicz, 'I cambiamenti del codice civile polacco dopo 1989 possono essere trattati come segno del ritorno alla tradizione romanistica?' in Petr Bělovský and Martin Skřejpek (eds), The Roman Law Tradition in Societies in Transition (Právnická Fakulta Univerzity Karlovy w Praze 2003).

${ }^{51}$ Rafał Mańko, 'Legal Transfers in Europe Today: Still "Modernisation Through Transfer?"' in Paulina Bieś-Srokosz, Jacek Srokosz and Ewelina Żelasko-Makowska (eds), Mutual Interaction Between Contemporary Systems and Branches if Law in European Countries (AJD 2017).

${ }^{52}$ For an insightful exploration of this phenomenon, from the perspective of legal culture, see recently Michal Bobek (ed), Central European Judges Under the European Influence: The Transformative Power of the EU Revisited (Hart 2015).

53 cf Giaro (n 29) passim.

54 cf Kukovec (n 15) 409.
} 
that definition. The notion of 'legal families' stems from comparative law, where it has been greatly popularised by the great comparatists of the $20^{\text {th }}$ century - Zweigert and Kötz, David and Merryman. According to David a legal family comprises jurisdictions whose lawyers share a common methodology to the extent of being able to 'handle' one another's law, adding an additional criterion that the respective legal systems must be based on common philosophical, political and economic principles. ${ }^{55}$ The latter criterion seems somewhat artificial and redundant because if the political and economic system is completely different, than lawyers will not be able to handle the respective legal materials with ease.

The German comparatists Zweigert and Kötz, in turn, posited that the criterion for grouping legal systems into legal families should be 'legal style'. They defined the latter notion by pointing to four constitutive elements: (i) historical background and development of a legal system, (ii) predominant and characteristic mode of legal thought, (iii) acknowledged sources of law and (iv) ideology understood as a religious or political conception of society. ${ }^{56}$ The fourth criterion (specifically understood 'ideology') resembles David's notion of the basic philosophical, political and economic principles of a society. Indeed, the recent ideological splits between the East and West in Europe show that this criterion - perhaps seemingly redundant in the now past epoch of 'end of history', starts to play, once again, an important differentiating role. As to the criteria of legal thought (ii) and sources of law (iii), we see a common element with David's theory, since these two elements impact whether lawyers from country A will be able to deal with legal materials from country $\mathrm{B}$. We welcome the addition of historical background and development (i) which - as we have pointed out above - we consider of paramount importance for the shape of legal culture. Furthermore, we note that both approaches have in common the rejection of the content of legal norms as such to be indicators of a legal family, owing to their relatively easy mutability, as opposed to deeper layers of legal culture, informed by legal traditions. ${ }^{57}$

Whilst some authors use the notions of legal family and legal tradition interchangeably, ${ }^{58}$ or alternatively, ${ }^{59}$ it seems that each concept should be distinguished and employed simultaneously in order to account for the historical origins of legal cultures belonging to one group (family). ${ }^{60}$ According to this conceptual convention, a 'legal family' is understood as referring to a contemporary and existing socio-legal reality, whilst a 'legal tradition' refers to one of many historical layers within a given legal culture. ${ }^{61}$ The notion of 'legal style', which we take from Zweigert and Kötz, is a useful tool to discern between various legal families and legal traditions.

\footnotetext{
55 Večeřa, Urbanová and Klusoňová (n 45) 12.

56 Zweigert and Kötz (n 8) 68-72.

57 cf Kaarlo Tuori, Legal Culture and the General Societal Culture, in Private Law (n 49) 32.

${ }^{58}$ See e.g. MA Glendon, MW Gordon and C Osakwe, Comparative Legal Traditions (WEST 1985).

59 Thus Glenn speaks of a legal tradition where Zweigert and Kötz (n 8) would speak of a legal family.

${ }^{60}$ Mańko (n 5) 4.

${ }^{61}$ Rodolfo Sacco, 'The sub-Saharan legal tradition' in Mauro Bussani and Ugo Mattei (eds), The Cambridge Companion to Comparative Law (Cambridge University Press 2012) 313 343, 314; Tuori (n 57) 32.
} 
An obvious added value of distinguishing between the concept of a 'legal family' and of a 'legal tradition' is that it allows accounting for the plurality of legal traditions which have jointly moulded the legal cultures belonging to one legal family. ${ }^{62}$ Thus, for instance, whilst contemporary Italian legal culture is considered to belong to the Romanic Legal Family, it was also influenced by the Germanic Legal Tradition. ${ }^{63}$ Within Central Europe, we can speak of such divergent influences depending on the area of law, for instance one can note the penetration of German (rather than French or American) constitutional concepts after 1989, even in those countries where remaining part of the legal system was moulded under French or Austrian influence.

\section{Legal Style as Fundamental Notion}

In order to answer the fundamental question, namely whether there is a 'Central European Legal Family', resort must be made to the chief criterion, namely legal style. Despite our critique of the fourth element of style (ideology), if it is treated as a stand-alone element, we do concede that the manifestations of ideology in law should be taken into account. Importantly, we do not intend to prejudge the answer to the question whether a Central European Legal Family exists, at this point. However, we posit that the fourpronged definition of 'legal style' put forward by Zweigert and Kötz, could provide for the axis of a long-term research endeavour, aimed at verifying or disproving the hypothesis of Central Europe's legal-cultural distinctiveness.

Furthermore, we believe that the question of a Central European Legal Family needs to be approached dynamically, in the sense that legal families are not eternal, but emerge, merge, split and disappear over time. Therefore, even if the thesis were proven that the Central European Legal Family exists today, in 2016, it may well be that as processes of legal integration progress, it will submerge, say, by 2026. Likewise, the fact that the Central European Legal Family exists currently, does not preclude the fact that it did not exist, say, in the $18^{\text {th }}$ century, but emerged, for instance, only in the $20^{\text {th }}$ century, and so forth. The same applies to the possible mergers and divisions of legal families. We all know that until 1989 it was commonly accepted that a Socialist Legal Family exists. However, when the Soviet Union was dismembered and the former Soviet bloc in Central Europe opted for a reWesternisation of their legal systems, the notion of a Socialist Legal Family was abandoned. It would be impossible to claim today that such a family still exists, even if it is plausible to claim that a Socialist Legal Tradition still continues to impact our legal life in Central and Eastern Europe, so to say, from beyond the grave. ${ }^{64}$ Therefore, our findings concerning Central Europe today could be modified in the future. A dialectical approach - grasping phenomena in their dynamic - is therefore appropriate here. Specifically, the question of a Central European vs. Central and Eastern European legal family is one which is evolving and may change in line with the overall dynamic of legal development trajectories in the region.

\footnotetext{
${ }^{62}$ Mańko (n 5) 4.

${ }^{63}$ Barbara Pozzo, 'Comparative Law and Language' in Comparative Law (n 61) 92-93.

${ }^{64}$ Jaakko Huusa, A New Introduction to Comparative Law (Hart 2015) 219-220.
} 
Following these caveats, let us now briefly examine the possible arguments in favour of a Central European legal family today.

\section{Applying the Theoretical Considerations to Central Europe}

As regards the first element of legal style - the historical origins of a group of legal systems - we must point out that recent legal history (19451989 ) is certainly a common factor. But also the $19^{\text {th }}$ century of Central European legal history brings to the fore a number of common traits, the most important ones being legal peripherality (either as parts of foreign empires, or as weak, newly independent nations) and, as a consequence, a massive exposure to legal transfers (from the West). ${ }^{65}$ Despite the fact that the sources of those transfers could be different (German, French or Austrian law), nevertheless the formal element of being the object of legal transfers, and the ensuing consequences of local legal cultures, is a strong common factor. What is more, the wholesale reception of continental Western laws in the 19th century led, as a rule, to the erasure of traces of earlier local legal cultures and traditions. ${ }^{66}$ Furthermore, there was no earlier tradition of Roman law reception, unlike in the West. ${ }^{67}$

The second hypothetical factor of legal style which brings our countries together is the predominant mode of legal thought. There is an ongoing debate as to whether so-called 'hyperpositivism' ('ultra-formalism') can be indicated as such a factor. ${ }^{68}$ Not wishing to enter into this debate at this stage, we would nevertheless like to indicate that we consider this argument to be of potential significance, subject to further investigation.

The third factor - element - of legal style is acknowledged sources of law. It is well known that our region, in line with its strong positivistic preponderances, is rather sceptical about the possibility of treating precedent as a source of law. Whilst, for instance, Dutch jurists will speak openly of the law-making functions of the Hoge Raad, Polish or Czech jurists would not speak about the law-making role of the Sad Najwyższy or Nejvyšši soud, respectively. We would rather speak of those courts interpreting the law, rather than creating it. Actually, the debate about the role of judicial case-law as a source of law was the object of 'wars of courts' between the supreme and

\footnotetext{
${ }^{65}$ For an overview see especially Giaro (n 29) vol 1.

${ }^{66}$ For Poland see Rafał Mańko, 'Unification of Private Law in Europe from the Perspective of Polish Legal Culture’ (2007-2008) 11 Yearbook of Polish European Studies 109, 115. Hungary was an exception in this respect.

${ }^{67}$ Giaro (n 26) 4-5.

${ }^{68}$ Pro Zdeněk Kühn, 'Worlds Apart: Western and Central European Judicial Culture at the Onset of the European Enlargement' (2004) 52.3 American Journal of Comparative Law 531; Tomasz Milej, 'Europejska kultura prawna a kraje Europy Środkowej i Wschodniej' (2008) 15.1 Przegląd Legislacyjny 60; Alan Uzelac, 'Survival of the Third Legal Tradition?' (2010) 49 Supreme Court Law Review 377; Kühn (n 11), passim; Mańko (n 5); Mańko (n 11); Mańko, 'Weeds in the Gardens of Justice? The Survival of Hyperpositivism in Polish Legal Culture as a Symptom/Sinthome' (2013) 7.2 Pólemos - Journal of Law, Literature and Culture 207Contra, recently, Péter Cserne, 'Formalism in Judicial Reasoning: is Central and Eastern Europe a Special Case?' in Central European Judges (n 52). With regard to Russia see Vladislav Starzhenetskiy, 'Property rights in Russia: reconsidering the socialist legal tradition' in Lauri Mälksoo and Wolfgang Benedek (eds), Russia and the European Convention of Human Rights: The Strasbourg Effect (Cambridge University Press 2017) in whose view hyperpositivism 'which Russia inherited from its Soviet, socialist, past, represents perhaps the most serious challenge to transformation and illuminates the high level of social inertia that makes the Russian legal system so resistant to changes' (ibid 300).
} 
constitutional courts in our countries, with the more Westernized constitutional courts trying to force the notion of precedent (of course, made by themselves) down the throats of more traditionally oriented supreme and ordinary courts. ${ }^{69}$

The fourth and final aspect of style identified by Zweigert and Kötz was that of ideology. It is pretty obvious that they needed it to differentiate the Socialist Legal Family from religious legal systems, such as Islamic law. We have expressed, above, our scepticism about this criterion; nonetheless it is still worthwhile to address it, especially if we give ideology a broad meaning capable of encompassing all extra-legal phenomena of a superstructural nature which can impact upon the actual functioning of the juridical in all its facets. In this context, the recently identified differences in approaching national sovereignty and constitutionalism in our region could come into play as differentiating factors. ${ }^{70}$ Likewise, the presence of ideological projects opponent to Western European demo-liberal consensus, such as republicanism, could be taken into account. ${ }^{71}$ Furthermore, if we agree that law is part of culture (of $a$ culture of a given society or region), and that the culture which surrounds the law impacts upon the law's interpretation and application, ${ }^{72}$ then the undoubtable cultural differences between Central Europe and Western Europe also militate in favour of speaking of a Central European Legal Family, based on Central European culture. Of course, both the matters of ideology and culture require a deeper socio-legal and historical research, but the trajectories of development outlined above, coupled with current trends in this sphere could be moulded into an argument aimed at claiming Central Europe's difference from the West.

\footnotetext{
${ }^{69}$ On the Polish case see Rafał Mańko, "War of Courts" as a Clash of Legal Cultures: Rethinking the Conflict Between the Polish Constitutional and Supreme Court Over "Interpretive Judgements" in Michael Hein et al (ed), Law, Politics, and the Constitution: New Perspectives from Legal and Political Theory (Peter Lang 2014). For the Czech case see e.g. Kühn (n 11) 194-195, 200-207.

${ }^{70}$ See e.g. Paul Blokker (ed), New Democracies in Crisis? A Comparative Constitutional Study of the Czech Republic, Hungary, Poland, Romania and Slovakia (Routledge 2013); Bojan Bugarič, 'A crisis of constitutional democracy in post-Communist Europe: "Lands inbetween” democracy and authoritarianism' (2015) 13 International Journal of Constitutional Law 219.

${ }^{71}$ The issue of republicanism as a political ideology in today's Poland was discussed by several speakers at the recent conference in Karpacz entitled "Konstytucjonalizm. Z zagadnień teorii i filozofii prawa" [Constitutionalism: Selected Issues of Legal Theory and Philosophy of Law] (24-27 September 2017). In particular, the topic was discussed by Tomasz Bekrycht in his paper 'Republikanizm, liberalizm, konstytucjonalizm' [Republicanism, Liberalism, Constitutionalism] and Wojciech Ciszewski in his 'Republikańskie odczytanie Konstytucji RP' [A Republican Reading of the Constitution of the Republic of Poland]. The paper by Ciszewski is forthcoming in the Przegląd Konstytucyjny.

${ }^{72}$ Martin Škop, “'Preferred Reading” of Legal Texts' (2005) 5.1 Wroclaw Review of Law, Administration and Economics 95. Cf Manuel Guţan, 'Introduction: Judicial Culture as Vector of Legal Europeanization' in Manuel Guţan and Bianca Selejan Guţan (eds), Europeanizaton and Judicial Culture in Contemporary Democracies (Editura Hamangiu 2014) 1: 'Understanding law in its cultural determinacies leads the comparatist beyond the legal texts and make it sensitive to specific patterns of legal reasoning, beliefs, assumptions, behaviours and practices belonging to a particular human community (...) emphasizing the intimate cultural links underlying a distinct epistemological community.'
} 


\section{EXCURSUS: Legal LANGUAGE AND LEGAL CULTURE IN CENTRAL EUROPE}

Once we have addressed the possibility of positing a Central European Legal Family, one cannot escape the problem of the language in which we are venturing this endeavour - the choice of a particular language is not neutral, it can affect the understanding and conceptualisation of phenomena, including juridical ones. ${ }^{73}$ In casu, the present paper is written in English, although it is neither a native nor an official language in any Central or Eastern European country, nor even a language of any of its neighbours. The problem is, however, deeper. Although similar perspectives on some legal issues shared in our region do exist, no general terminology, or general legal language, covering main legal issues has been established. Only after 1991, or more precisely after deepening European integration, have some unification tendencies even begun in legal language. As a modern lingua franca the English language has arisen, shared even between Central European legal scholars. Paradoxically, these unification tendencies in language can affect the emergence of a common legal identity more significantly than the shared experience of socialist law. The pressure on a general language present in European law - albeit not strong and always connected to proclaimed protection of national languages - causes sequential and discreet unification of legal ideas and thought. On the one hand, this process can produce closer cooperation between Central European states, on the other; however, it can produce an indiscriminating system. As Přibán points out, we should reveal how general language or its formal structures and the apparent impersonality created by language entrenches social and political inequality and unfairness. ${ }^{74}$

From the standpoint of legal theory developed on the fundamentals of the ideology of 'hyperpositivism', there is one objective universal legallinguistic project which includes the possible language of legal theory. Differences between national languages are not essential. Theoretical terminology tends towards universalisation, which itself tends to have unforeseen global effects. In this vision there is only one picture of law, which claims to provide content for all law in different cultures. In a space where the idea of a Central European Legal Family appears from time to time, such an approach is more and more seductive. Consequently, one has the impression that the single word 'law,' which may be translated into any language, has the same meaning across all languages, as if there were a material, linguistic, and contextual determination to the word. This can be seen in several sources of general jurisprudence and specifically applies to the English language, which is becoming the universal language of Central European legal studies.

The particular cause of the linguistic and contextual dominance of English may be found in its influence over global judicial systems with predictable consequences in Central Europe. Leading judicial institutions, such as, for example, the European Court of Human Rights, make decisions

\footnotetext{
${ }^{73}$ Martin Škop, 'The Importance of Being a Linguist: Critical Legal Thought in Central Europe' in Law and Critique (n 3) 32.

${ }^{74}$ Jiř́i Přibáň, 'Kritická Právní Věda a Sociologie Práva' (2001) 140 Právník 1211, 1224.
} 
which apply to general legal issues and since their daily work language is English $^{75}$, one might expect they derive inspiration from many sources written in English, irrespective of their context. This discreet language unification can lead to the loss of history or context. The French philosopher Jean Baudrillard argues: 'We require a visible past, a visible continuum, a visible myth of origin, which reassures us about our end.' 76 The past enables us to trace the trajectory of Central European Law. Legal tradition, interpretation, or the practice of law are very closely connected with law's history and its specific meanings. If the past, rooted in the language, will be forgotten, specific patterns of any national law can be forgotten too. As observed by Clifford Geertz, only the mental object capable of being expressed in a universal general language is relevant. ${ }^{77}$ The particular world of law is submitted to the universal and globally shared vision of ideal law. The capital gained in Central Europe legal scholars in times of Actually Existing Socialism or subsequent transformation can be wasted. In translation it is "impossible to preserve original meaning without modification." Walter Benjamin observed, even though there can be the same object in both languages, modes of their intentions will be different. ${ }^{79}$

The regulation of (legal) science and criteria of academic excellence may also be influencing factors in this context. In order to meet the quantitative criteria used for various evaluations of research outputs (existing in Central Europe and beyond), one has to publish his or her work in scientific journals, preferably the journals with so-called impact factor. The most significant scholarly publications tend to be American journals. ${ }^{80}$ To publish in them, the author has to provide insights into the object of research to American readers. However, it is likely that these readers will not be familiar with either Central European law or the judicial decisions of courts located in Central Europe. It is therefore common to find that authors submitting to such journals focus only on the contexts familiar to reviewers. To secure publication, they have to adapt their use of universal English language when explaining and discussing domestic legal issues. They also have to take into consideration all kinds of possible limitations that may arise due to such translation.

This situation springing from the specific scientometrics used in Central Europe countries ${ }^{81}$ can affect the traditional cooperation between traditional partners. Because of similar legal traditions and similar experiences it should be natural to publish academic papers in legal journals in Central Europe. But - e.g. in the Czech Republic - this publication will be

\footnotetext{
${ }^{75}$ Olga Łachacz and Rafał Mańko, 'Multilingualism at the Court of Justice of the European Union: Theoretical and Practical Aspects' (2013) 34 Studies in Logic, Grammar and Rhetoric 75, 80.

76 Jean Baudrillard, Simulacra And Simulation (Ann Arbor 1994) 10.

${ }^{77}$ Clifford Geertz, The Interpretation Of Cultures: Selected Essays (Basic Books 1973) 172.

78 Rafał Mańko, 'Multilingualism, Divergent Authentic Versions of a Legal Rule and Legitimate Expectations of Individuals' (2016) 45 Studies in Logic, Grammar and Rhetoric 141.

${ }^{79}$ Walter Benjamin, Illuminations (Schocken Books 2007) 74.

80 See e.g. "Law Journals: Submissions and Ranking, 2007 - 2014" $<$ http://lawlib.wlu.edu/LJ/index.aspx> accessed 15 January 2018.

${ }^{81}$ Although there are some differences among CE countries, the principle are very similar. 
much less evaluated than if were to be published in an English language journal. There is even pressure not to publish in any Central European language because this kind of publication is less evaluated - regardless of the content of the publication. Although the cooperation between scholars is still at a high level, this kind of influence cannot be underestimated.

The Central European countries face the threat of loss of their specific legal culture. Hence culture can be understood as a pattern of meanings that have evolved throughout history, i.e. meanings which are included in symbols connected with the means of communication by which people reflect on their life in the broadest sense. ${ }^{82}$ Culture links the meanings, language or means of communication, and the way one understands oneself and one's surroundings. Manipulating language may result in changes not only to law as a symbolic system, but also to society. If the legal science (jurisprudence) focuses on general issues and will reflect only global topics, then it is going to lose the ability to define or to operate as a cultural agent. Becoming conscious of this threat should not lead to strict protection of "national culture". It is important to protect pluralism. In these processes of unification, an alternative voice can be irretrievably lost.

\section{CONCLUSIONS: BREAKING AWAY FROM PERIPHERALITY}

Peripherality is, with all due respect to the scientific objectivity of the concept, a humiliating condition. To be peripheral means to be subject to the economic, political and - indeed - cultural hegemony of a certain Centre. Central Europe has a long experience of being peripheral, also in legal terms. This experience is being refreshed today, as our region is the subject of an unprecedented influx of legal transfers which are beyond the control of its legislators. Attempts at accommodating them to national legal cultures are, at best, limited to questions of form and decorum, ${ }^{83}$ but cannot affect the legal substance. However, what our Central European history definitely teaches us is that no empire is eternal and no domination is beyond resistance. Both in 1918 and 1989 our legal elites were taken by surprise and it took them some time to find themselves in the new situation. In Poland, only in the 1930s a partial national recodification of private law took place. Today, 28 years after the transformation, the 'good old' socialist Civil Code is still in force. ${ }^{84}$ True, the legal community is inherently conservative; legal culture has a tendency to lag behind, and especially dogmatic legal science is far from being a critical force, capable of undermining hegemonic narratives. Nonetheless in a world which has lost its illusion of stability and 'end of history', more than ever, Central Europe needs a solid and proper legal identity. We must come to

\footnotetext{
82 cf Geertz (n 77) 89.

${ }^{83}$ An interesting example of such an effort is the recodification of the law of sale in Poland in 2014. Cf Piotr Tereszkiewicz, 'The Reform of Polish Sales Law - Re-implementing the Consumer Sales Directive' (2016) 4 Journal of European Consumer and Market Law 175.

${ }^{84}$ In the Czech Republic the new Civil Code, as the symbolical replacement of the socialistic code, was adopted in 2012 and entered into force in 2014. However, the new Civil Code follows the tradition of Austrian Allgemeines bürgerliches Gesetzbuch für die gesammten Deutschen Erbländer der Österreichischen Monarchie (1811). More on the new Czech Civil Code see Petr Dostalík and Ondřej Horák, Zmiany w czeskim prawie prywatnym“ (2016) 24 Forum Prawnicze 16.
} 
terms both with our legal past - the epoch of domination of foreign empires and the epoch of Actually Existing Socialism - and to critically approach our legal present, looking forward to possible paths of future development. To this end, we need to define ourselves in terms of neighbouring legal families, with their distinct legal identities. On the one hand, we cannot agree to being amalgamated in an unqualified manner with the Romanic and/or Germanic legal family - Central Europe is certainly distinct from Western Europe and its legal families, even if it was (and is again) subjected to the taking in of legal transfers originating from that region. Of course, the gesture of (re)establishing Central Europe as a legal family is a counter-hegemonic one, and therefore not easy or straightforward to take. Nonetheless, the stakes are high, and they are concerned both with the present and future politicojuridical developments of our region.

On the other hand, we need to come to terms with our selfidentification qua legal family vis-à-vis the Eastern European/Eurasian legal family, which we see as comprising Russia and most of the former Soviet republics, especially those integrating within the Eurasian Economic Community. We do have a partially shared legal past (Socialist Legal Tradition, and earlier Russian Legal Tradition of the imperial period); nonetheless it seems that currently we are different in terms of legal families. If, as we indicated in the introduction, the destruction of the Socialist Legal Family - dite 'dead and buried' - is the founding myth of the legal identity of our region, it will come as no surprise if we posit that the Socialist Family has split into two: the Central European one, and the Eastern European one which, due to its extension beyond the Caucasus and Ural - would be better termed as the Eurasian Legal Family. The latter is distinct from the Oriental Legal Families of China, India and the South-East Asian region, a topic which is beyond the scope of the present paper.

Legal taxonomy is political. This is a fact which we cannot deny, and proposing Central Europe as a sedes of a legal family we are making a conscious move. A move intended to underscore the similarities and common heritage, whilst concealing the differences. And, at the same time, a move distinguishing us from the West and the East, but not closing down channels of juridico-cultural communication. To the contrary, if the last three decades were marked by an unprecedented reception of juridico-cultural transfers from the West, and the previous decades (of Actually Existing Socialism) were marked by the infiltration of Soviet legal ideas, we hope that the selfidentification and self-determination of our legal communities qua Central Europe will be instrumental in promoting a greater equilibrium in the flow of legal ideas within geographical macrospaces.

All in all, certain aspects remain crucial for this task to be accomplished. First of all, we need to come to terms - especially on a scientific plane - with our socialist past. It cannot remain a terra incognita, a blackout' or a 'legal black hole'. We need to evaluate it consciously and critically. The first steps have been made; nonetheless, an objective and balanced reappraisal of the Soviet/socialist legal past and its impact upon the present is still a task to be accomplished.

Secondly, our legal science needs to analyse and explain the constitutional specificities of our region. Without the intent of evaluating or 
taking sides, we cannot deny that our traditions with that regard differentiate us from neighbouring legal families. The wholesale reception of (continental) Western European models after 1989 can no longer be seen as unproblematic. Again, certain research projects are making the first steps towards interpreting and explaining those tendencies in a scientific way, but at the same time there is a long way to go, and the dynamic of the phenomena under scrutiny poses an additional challenge to the scientific eye.

Thirdly, our methodological identity. Can Central (and Eastern) Europe escape from the trap of peripheral imitation? Is our juridicotheoretical imaginarium destined to persist as a receptacle for foreign ideas, mainly from the Anglo-American and Germanic worlds, or can we become a metatheoretically self-supporting scientific community? To date, most legal currents in theory and sociology of law have been imitative, or - at best creatively interpretive of intellectual transfers. Even critical legal scholars like the authors of the present paper - are, more or less correctly, being accused of transferring Western ideas into the Central European legal space, perhaps even in an untimely fashion. ${ }^{85}$ From a Polish perspective, the most original development in legal theory, to date, has been Artur Kozak with his famous project of juriscentrism, the most significant novelty originating in our part of Europe since the times of Leon Petrażycki and Eugen Ehrlich. Definitely, such examples of original Central and Eastern European legal thought need to be studied and promoted.

Fourthly and finally, the question of language. In Central Europe we are, unfortunately, blessed with the 'tower of Babel' syndrome. Our languages belong to four different families (Slavic, Romanic, Baltic, UgroFinish) and we have been subject to various linguistic hegemonies in the past and in the present. As we have pointed out, the use of a specific language in legal science, especially if it is heavily laden with semantic connotations (as English or German or French inevitably are), implies the extension of a given hegemonic discourse. Even the present paper - however critical it may be of the hegemony of legal English - has been written and published in English, although it is neither a language of any CEE country, nor of its direct neighbours. As a way out of this linguistic-political conundrum we can only propose a pluralistic approach, whereby a variety of languages are used concurrently in the scientific discourse. Patently, a domination of English alone is adverse to our critical and scientific agenda in Central Europe.

We can only hope that Central Europe (or 'Central and Eastern Europe', as the case may be) will become a permanent and solid concept on the socially constructed map of legal geography. Its place between Western Europe, on the one hand, and Eastern Europe/Eurasia on the other, requires a high degree of self-identification and self-consciousness, both in terms of legal identity and legal tradition. We consider the discourse of the Central European Legal Family as a strategically counter-hegemonic one, aimed at reconfiguring the perception of the legal field in our part of the world with view to countering its persistent peripherality. To put it in Lacanian terms, we want to liberate ourselves from the orientalising gaze of the Western big Other, breaking away from the Symbolic order in which we occupy an always

${ }^{85}$ Wojciech Zomerski, review of Mańko et al (ed.), Law and Critique in Central Europe, forthcoming in Państwo i Prawo. Cf Škop (n 73) 37. 
already peripheral position. Efforts towards the accomplishment of this daunting task have begun, ${ }^{86}$ but we hope that it only the beginning of a new intellectual tide.

\section{Bibliography}

Ajani G, Il modello post-socialista (3rd ed. Giapichelli 2008).

Baudrillard J, Simulacra and Simulation (Ann Arbor 1994).

Benjamin W, Illuminations (Schocken Books 2007). [1966])

Berger PL, Luckmann T, The Social Construction of Reality (Penguin, 1991

Blokker P (ed), New Democracies in Crisis? A Comparative Constitutional Study of the Czech Republic, Hungary, Poland, Romania and Slovakia (Routledge 2013).

Bobek M (ed), Central European Judges Under the European Influence: The Transformative Power of the EU Revisited (Hart 2015).

Bobek M, Kühn Z, Molek P, Polčák R, Vyhnánek L, Judikatura a právní argumentace (2nd ed., Auditorium 2013).

Bourdieu P, Masculine Domination (Stanford University Press 2001)

Bourdieu P, Passeron JC, Reproduction in Education. Society and Culture (SAGE 1990)

Bugarič B, 'A crisis of constitutional democracy in post-Communist Europe: "Lands in-between" democracy and authoritarianism' (2015) 13 International Journal of Constitutional Law 219.

Cserne P, 'Formalism in Judicial Reasoning: is Central and Eastern Europe a Special Case' in Bobek M, (ed), Central European Judges Under the European Influence: The Transformative Power of the EU Revisited (Hart 2015).

Czerewacz-Filipowicz K, Konopelko A, Regional integration processes in the Commonwealth of Independent States Area. Economic and political factors (Springer 2017).

Dębska H, Warczok T, 'The Social Construction of Femininity in the Discourse of the Polish Constitutional Court', in Mańko R, Cercel C, Sulikowski A (eds), Law and Critique in Central Europe: Questioning the Past, Resisting the Present (Counterpress 2016).

Dębska H, 'Strategia wielopozycyjności w półperyferyjnym polu prawnym. Homo academicus na rynku', in Tomasz Zarycki (ed), Polska jako peryferie (Scholar 2016).

Dostalík P, Horák O, 'Zmiany w czeskim prawie prywatnym' (2016) 24 Forum Prawnicze 16.

Douzinas C, On a Recent Change of Tone in Politics and Law, in Mańko R, Cercel C, Sulikowski A, (eds), Law and Critique in Central Europe: Questioning the Past, Resisting the Present (Counterpress, 2016)

Foucault M, Surveiller et punir. Naissance de la prison (Gallimard 1975).

Fudge TA, The Hussite Revolution (2004) 79 Speculum: A Journal of Medieval Studies 1142.

Geertz C, The Interpretation of Cultures: Selected Essays (Basic Books 1973).

\footnotetext{
${ }^{86}$ One can mention here the establishment of the Central and Eastern European Network of Legal Scholars (CENEELS) in 2015 and its series of annual conferences, touching upon the key issues of Central European legal culture (such as: continuity and discontinuity of legal culture following the 1989 transformation; remnants of socialist legal thinking; legal traditions and identities in Central and Eastern Europe). For details, see <http://www.ceenels.org/> accessed 15 January 2018.
} 
Giaro T, (ed.). Rechtskulturen des modernen Osteuropa: Traditionen und Transfers, 2 vols. (Vittorio Klosterman, 2006-2007).

Giaro T, Some prejudices about the legal tradition of Eastern Europe in Bronisław Sitek, Jakub J Szczerbowski and Aleksander W Bauknecht (eds), Comparative Law in Eastern and Central Europe (Cambridge Scholars 2014).

Giaro T, The Legal Tradition of Eastern Europe: Its Rise and Demise (2011) 2.1 Comparative Law Review 1.

Glendon MA, Gordon M, Osakwe C, Comparative Legal Traditions (WEST 1985).

Glos GE, Czechoslovak Civil Code of 1964 and Its 1982 Amendment within the Framework of Czechoslovak Civil Law 1984), 6 New York Law School Journal of International and Comparative Law 215.

Godek S, 'III Statut Litewski w dobie porozbiorowej - stan badań nad dziedzictwem prawa litewskiego' in W Walczak \& K Łopatecki (eds), Stan badań nad wielokulturowym dziedzictwem prawnym dawnej Rzeczypospolitej (Instytut Badań nad Dziedzictwem Kulturowym Europy 2010).

Grodziski S, 'Prace nad kodyfikacją i unifikacją polskiego prawa prywatnego (1919-1947)’ (1992) 1.1-4 Kwartalnik Prawa Prywatnego 9.

Grzybowski S, 'Zagadnienia kodyfikacji polskiego prawa cywilnego (Organizacja i wyniki pracy 1919-1992) )' (1992) 1.1-4 Kwartalnik Prawa Prywatnego 91.

Guțan M, 'Introduction: Judicial Culture as Vector of Legal Europeanization' in Manuel Guţan and Bianca Selejan Guţan (eds), Europeanizaton and Judicial Culture in Contemporary Democracies (Editura Hamangiu 2014) 1

Hamza G, 'Continuity and Discontinuity of Private/Civil Law in Eastern Europe After World War II', (2006) 12 Fundamina: A Journal of Legal History 48.

Hauner M, 'Crime and Punishment in Communist Czechoslovakia: The Case of General Heliodor Píka and his Prosecutor Karel Vaš' (2008) 9 Totalitarian Movements and Political Religions 335.

Hesselink MW, 'The New European Legal Culture: Ten Years On', in G Helleringer \& KP Purnhagen (eds.), Towards a European Legal Culture (C.H. Beck-Hart-Nomos 2014).

Huusa J, A New Introduction to Comparative Law (Hart 2015).

Jabłoński $\mathrm{P}$ et al. (eds). Perspektywy juryscentryzmu (Prawnicza i Ekonomiczna Biblioteka Cyfrowa 2011).

Kelemen K, Fekete B, 'How Should the Legal Systems of Eastern Europe Be Classified Today?' in Attila Badó et al (eds), International Conference for the 10th Anniversary of the Institute of Comparative Law of the University of Szeged (Universitätsverlag Potsdam 2014).

Kelemen, K. 'I sistemi giuridici dell'Europa orientale' in Vittoria Barsotti \& Vincenzo Varano (eds), La tradizione giuridica occidentale: Testo e materiali per un confronto civil law common law (5th ed. Giapichelli 2014).

Kötz H, 'Preface to the Third Edition' in Konrad Zweigert and Hein Kötz, Introduction to Comparative Law (3rd ed., Clarendon Press 1996) 2000).

Kozak A, Granice prawniczej władzy dyskrecjonalnej (Kolonia Limited

Kozak A, Myślenie analityczne w nauce prawa i praktyce prawniczej (ed. Maciej Pichlak, WUWr 2010).

Kozioł AA, 'Organizacja prac nad prawem cywilnym w Polsce w latach 19451946’ (2005) 7 Z Dziejów Prawa 174.

Kühn Z, Aplikace Práva Soudcem v ére Středoevropského Komunismu a Transformace: Analýza Přičin Postkomunistické Právni Krize (C.H. Beck 2005).

Kühn Z, The Judiciary in Central and Eastern Europe: Mechanical Jurisprudence in Transformation? (Martinus Nijhoff 2011). 
Kühn Z, 'Worlds Apart: Western and Central European Judicial Culture at the Onset of the European Enlargement' (2004) 52.3 American Journal of Comparative Law 531.

Kukovec D, 'Law and the Periphery' (2015) 21 European Law Journal 406.

Lane T, Wolański M, Poland and European Integration: The Ideas and Movements of Polish Exiles in the West, 1939-91 (Palgrave MacMillan 2009).

Łachacz O, Mańko R, 'Multilingualism at the Court of Justice of the European Union: Theoretical and Practical Aspects' (2013) 34 Studies in Logic, Grammar and Rhetoric 75.

Leff CS, National Conflict in Czechoslovakia: The Making and Remaking of a State, 1918-1987 (Princeton University Press 2014).

Mańko R, 'Demons of the Past? Legal Survivals of the Socialist Legal Tradition in Contemporary Polish Private Law' in Mańko R, Cercel C, Sulikowski A (eds), Law and Critique in Central Europe: Questioning the Past, Resisting the Present (Counterpress, 2016).

Mańko R, 'Is the Socialist Legal Tradition "Dead and Buried"? The Continuity of Certain Elements of Socialist Legal Culture in Polish Civil Procedure' in Thomas Wilhelmsson (ed), Private Law and the Many Cultures of Europe (Kluwer 2007).

Mańko R, 'Legal Transfers in Europe Today: Still "Modernisation Through Transfer"?' in Paulina Bieś-Srokosz, Jacek Srokosz and Ewelina ŻelaskoMakowska (ed.), Mutual Interaction Between Contemporary Systems and Branches if Law in European Countries (AJD 2017).

Mańko R, 'Multilingualism, Divergent Authentic Versions of a Legal Rule and Legitimate Expectations of Individuals' (2016) 45 Studies in Logic, Grammar and Rhetoric 141.

Mańko R, 'Quality of Legislation Following a Transition from Really Existing Socialism to Capitalism: A Case Study of General Clauses in Polish Private Law' in Jānis Rozenfelds et al. (ed), The Quality of Legal Acts and its Importance in Contemporary Legal Space (University of Latvia Press 2012).

Mańko R, 'Survival of the Socialist Legal Tradition? A Polish Perspective' (2013) 4.2 Comparative Law Review 1.

Mańko R, 'Symbolic Violence in Technocratic Law and Attempts at its Overcoming: Politicisation Through Humanisation?' (2017) 11 Studia Erasmiana Wratislaviensia 31.

Mańko, R. 'The Culture of Private Law in Central Europe After Enlargement: A Polish Perspective' (2005) 11 European Law Journal 527.

Mańko R, 'Unification of Private Law in Europe from the Perspective of Polish Legal Culture' (2007-2008) 11 Yearbook of Polish European Studies 109.

Mańko R, 'Weeds in the Gardens of Justice? The Survival of Hyperpositivism in Polish Legal Culture as a Symptom/Sinthome' (2013) 7.2 Pólemos - Journal of Law, Literature and Culture 207.

Mańko R, "War of Courts" as a Clash of Legal Cultures: Rethinking the Conflict Between the Polish Constitutional and Supreme Court Over "Interpretive Judgements"' in Michael Hein et al (ed), Law, Politics, and the Constitution: New Perspectives from Legal and Political Theory (Peter Lang 2014).

Mańko R, Cercel C, Sulikowski A, 'Law and Critique in Central Europe: Laying the Cornerstone' in Mańko R, Cercel C, Sulikowski A (eds), Law and Critique in Central Europe: Questioning the Past, Resisting the Present (Counterpress 2016).

Mason JW, The Dissolution of the Austro-Hungarian Empire, 1867-1918 (Routledge 2014).

Milej T, 'Europejska kultura prawna a kraje Europy Środkowej i Wschodniej' (2008) 15.1 Przegląd Legislacyjny 60. 
Musil J, 'Czechoslovakia in the Middle of Transition' (1992) Czechoslovak Sociological Review 5.

Nazmutdinov BV, [Назмутдинов, Б.В.] Законы из-за гранищы: Политикоправовые аспекты классического евразийства (Норма 2017).

Örücü E, 'Comparatists and Extraordinary Places' in Pierre Legrand and Roderick Munday (eds.), Comparative Legal Studies: Traditions and Transitions (Cambridge University Press 2003).

Pichlak M (ed.), Profesjonalna kultura prawnicza (Scholar 2012).

Pichlak M, 'Artura Kozaka cierpliwość wobec prawa' (2014) 3.1 Filozofia Publiczna i Edukacja Demokratyczna 226.

Pietrzykowski T, Naturalizm i granice nauk prawnych. Esej z metodologii prawoznawstwa (Wolters Kluwer 2017).

Pozzo B, 'Comparative Law and Language' in Mauro Bussani and Ugo Mattei (eds), The Cambridge Companion to Comparative Law (Cambdidge University Press 2012).

Přibáň J, 'Kritická Právní Věda a Sociologie Práva' (2001) 140 Právník 1211.

Quill AM, 'To Prosecute or Not to Prosecute: Problems Encountered in the Prosecution of Former Communist Officials in Germany, Czechoslovakia, and the Czech Republic' (1996) 7 Indiana International and Comparative Law Review 165.

Sacco R, 'The sub-Saharan legal tradition' in Mauro Bussani and Ugo Mattei (eds), The Cambridge Companion to Comparative Law (Cambdidge University Press 2012).

Said EW, Orientalism (Penguin Classic 2003 [1978]).

Sluga G, 'Bodies, Souls and Sovereignty The Austro-Hungarian Empire and the Legitimacy of Nations' (2001) 1 Ethnicities 207.

Smith A, Timár J, 'Uneven Transformations: Space, Economy and Society 20 Years after the Collapse of State Socialism' (2010) 17 European Urban and Regional Studies 115.

Starzhenetskiy V [Старженецкий BB], 'Property rights in Russia: reconsidering the socialist legal tradition' in Lauri Mälksoo and Wolfgang Benedek (eds), Russia and the European Convention of Human Rights: The Strasbourg Effect (Cambridge University Press 2017).

Stawarska-Rippel, A. Elementy prywatne i publiczne $w$ procesie cywilnym $w$ świetle prac kodyfikacyjnych w Polsce (1918-1964). Studium historycznoprawne (Wydawnictwo Uniwersytetu Śląskiego 2015).

Stein P, Roman Law in European History (Oxford University Press 1999).

Stroiński RT, 'Report from Poland' (2006) 3 European Company Law 39.

Škop M, “Preferred Reading” of Legal Texts' (2005) 5.1 Wroclaw Review of Law, Administration and Economics 95.

Škop M, 'The Importance of Being a Linguist: Critical Legal Thought in Central Europe' in Mańko, R, Cercel C, Sulikowski A (eds), Law and Critique in Central Europe: Questioning the Past, Resisting the Present (Counterpress 2016).

Tereszkiewicz P, 'The reform of Polish Sales Law - Re-implementing the Consumer Sales Directive' (2016) 4 Journal of European Consumer and Market Law 175.

Tihany LC, 'The Austro-Hungarian Compromise, 1867-1918: A Half Century of Diagnosis; Fifty Years of Post-Mortem' (1969) 2 Central European History 114.

Tuori K, 'Legal Culture and the General Societal Culture' in Thomas Wilhelmsson (ed), Private Law and the Many Cultures of Europe (Kluwer 2007).

Uzelac A, 'Survival of the Third Legal Tradition?' (2010) 49 Supreme Court Law Review 377.

Van Elsuwege P, From Soviet Republics to EU Member States: A Legal and Political Assessment of the Baltic states' accession to the EU (Brill 2008). 
Varga C, 'Introduction. Complexity of the Challenge Facing Central and Eastern Europe' in Armin Hoeland Gessner and Csaba Varga (eds), 1 European Legal Cultures (Dartmouth 1996).

Večeřa $\mathrm{M}$, Urbanová $\mathrm{M}$, Klusoňová $\mathrm{M}$, Právní vědomí $v$ teoretickoempirickém pohledu (Masarykova univerzita 2015).

Vinokurov E, 'Eurasian Economic Union: Current state and preliminary results' (2017) 3 Russian Journal of Economics 54.

Williams K, Fowler B, Szczerbiak A, 'Explaining Lustration in Central Europe: A “post-Communist Politics" Approach' (2005) 12 Democratization 22.

Wojciech Zomerski, book review of: Mańko R, Cercel C, Sulikowski A (eds), Law and Critique in Central Europe: Questioning the Past, Resisting the Present (Counterpress, 2016), forthcoming in Państwo i Prawo.

Wołodkiewicz W, 'I cambiamenti del codice civile polacco dopo 1989 possono essere trattati come segno del ritorno alla tradizione romanistica?' in Petr Bělovský and Martin Skřejpek (eds), The Roman Law Tradition in Societies in Transition (Právnická Fakulta Univerzity Karlovy w Praze 2003).

Žižek S, Enjoy your symptom! (Routledge 2001).

Žižek S, The Sublime Object of Ideology [1989] (Verso 2008). 